\title{
Empirical assessment of frauds on the financial performance of banking sector in Nigeria
}

Ogbeide, Sunday Oseiweh $\triangle \triangle$

Elizade University, Nigeria (Sunday.ogbeide@elizadeuniversity.edu.ng)

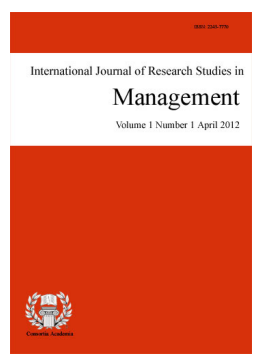

ISSN: $2243-7770$ Online ISSN: 2243-7789

OPEN ACCESS

\section{Abstract}

The aim of this study was to assess how frauds have affected the banking sector financial performance in Nigeria. Data spanning 1993 to 2016 period was used. The method of data analysis was co-integration and error correction mechanism. This method was employed to examine the short and long run relationships between the dependent and independent variables. The method was used after carrying out diagnostic tests. The finding from the estimation revealed that a three period lag of number of fraud cases has negative effect on banking sector financial performance and was statistically significant. One period lag of total amount involved in the fraud and one period lag of actual/ expected loss have negative signs on financial performance of banking sector in Nigeria and were statistically significant. Premised on the empirical finding obtained, the study recommends that banks should strengthen their internal control system in order to reduce fraud to the barest.

Keywords: fraud; size; actual/expected loss; return on equity; total amount involved 


\section{Empirical assessment of frauds on the financial performance of banking sector in Nigeria}

\section{Introduction}

The term fraud is not a new concept generally as it appears to be synonymous with the human nature. It takes its root from the heart of humans specifically since the fall of man from God's divine purpose through disobedience. Fraud is one of the evils people irrespective of status, age, ethnicity and religious and organization belonging/affiliation consciously and unconsciously indulge in through varying methods, approaches and tactics. Fraud may be seen as a social malady; while it keeps the perpetrators enriched and sometimes elevated in the inter temporal period it occurs, it however, causes pains, frustration, "losses" and economic retrogression to the victims be it individual, corporate bodies as well as nations at large. Fraud is a calculative attempt by an unsuspected party to deceive another for either financial gain or moral gain. Hence, Idolor (2010) notes that behavior which engenders fraud is a sort of evil purpose on the part of the perpetrator(s) to the disadvantage of a third party, in this case the victim of the frauds. Frauds are perpetrated in corporate organization such as banks and non- banks. It is a common knowledge that banks are into the business of performing the role of financial intermediation, collecting deposits from the excess units and making it available to the needing units via credit or loan which most often is on short-term basis. In view of this, the banking sector is regarded as one of the vulnerable sectors and a major contributor to the acceleration of the economy of Nigeria; ensuring growth, and positively affecting the lives of the citizenries. Today, Nigerian banks' image has been dragged to the 'mold'. The very professionalism and ethics of banking appear to have been grossly undermined in the banking sector. The banks seemed to have also lost substantial amount of their quality assets and integrity over the years locally and before the international communities, occasioned by the activities of fraudsters in which majority of them are bank officials.

Oseni (2006) says the frequent occurrence of frauds perpetrated by fraudsters in the Nigerian banking industry is quite alarming and worrisome to stakeholders; and it has even affected the confidence of investors. Corroborating this view, Olatunji and Adekola (2014) pointed out that the incessant development of fraud in Nigeria banks has become an embarrassment in addition with inability of the regulators and law enforcement agencies to combat the incidence of frauds and fraudsters successfully. These have even exacerbated very recently and the amounts of money lost increased astronomically. It is indeed, a pitiable and dismal state that most bankers have now allowed themselves to be caught in the web of frauds and chosen to make the term "banker official" synonymous with fraudsters.

Recently, there was a media report in Nigeria where a senior bank official had to humiliatingly kneel before a serving state governor in the Western part of Nigeria over a shady deal involving loans transaction, unhealthy/unethical deal with the governor, which hitherto was not meant to be disclosed to the public. Unfortunately, things fell apart, the center stage could not hold. It was glaring to the general public that bankers, who are supposed to be honest, avoid every fraudulent practice and display professionalism, have become pen robbers. These bad practices have a way of negatively influencing, degenerating to poor asset quality and devaluing of the bank capital, consequently the banking sector financial performance. The importance of banks in the banking sector cannot be overemphasized. They mobilize funds from the surplus units and channel the funds to the deficit units. These deficits units are more often the private business either for the purpose of expanding production capacity or for any other purpose with a view for enhancing the wealth of the shareholders and stakeholders in general. This underscores the rationale why banks are seen as very critical to the economy of any nation. Apart from banks playing the intermediation role, most customers see banks as the custodian of their hard earned currency. The belief is that banks have high level of integrity and professionalism to ensure safety of cash as part of function. 
According to Ogechukwu (2014) "today, the very integrity and survivability of these functions of Nigerian banks have been deteriorated in view of incessant frauds and accounting scandals. In fact, frauds have become endemic and systemic in the banking sector due to myriad of causative factors which are both internal and external in nature". In this regard, Oseni (2006) stresses that "incessant frauds in the banking industry are getting to a level at which many stakeholders in the industry are losing their trust and confidence". Idolor (2010) accentuate further that "the spate of frauds in the Nigerian banking sector has lately become a source of embarrassment to the nation as apparent in the securing attempts of the low enforcement agencies to success fully track down culprits". In furtherance of this view, Adeyemo (2012) opines that fraud in its effect reduces organizational assets and increases its liabilities; with regards to banking industry and it adversely affect confidence the general public, seriously affect the performance of banks, impede the going concern status of the bank and ultimately lead to bank failure.

This suggests there is a nexus between frauds and the performance of banks; the relationship could be negative or positive. Chiezey and Onu (2013) surmised that frauds inflict severe difficulties on banks and their customers. The associations between fraud and financial performance of banks have remained mixed and inconclusive". The world is changing constantly and is affected by stiff challenges, inclusive of frauds and fraud related issues. As such, the banking industry in Nigeria is not immune to it. On both theoretical and empirical fronts, fraud has been observed to drastically reduce the amount of funds in business organization, particularly the financial sector. In consonance with this view, Owolabi (2010) opines that fraud can ultimately result to bank poor performance and failure. "Fraud and fraudulent activities inflict severe financial difficulties on banks and their customers; they reduce the amount of money available to the development of the economy; to mitigate against this, banks in Nigeria need to take a drastic step to strengthen their internal control systems and the regulatory bodies have to improve their supervisory role in order to check and curtail the incidence of fraud and fraudulent activities in the banking industry in Nigeria" (Chiezey \& Onu, 2013). They stress that "in Nigeria, in spite of the banking regulation and bank examination by the Central Bank of Nigeria (CBN), the supervisory role of the Nigeria Deposit Insurance Corporation (NDIC) and the Chartered Institute of Bankers of Nigeria (CIBN), there is a growing concern about fraud and other unethical practices in the banking industry".

Evidence from the NDIC (2008) shows clearly that "the report of the examinations and special investigations indicate that some banks were still bedeviled with problems of fraud, weak board and management oversight, inaccurate financial reporting, poor book - keeping practices, non-performing insider related credits, declining asset quality and attendant large provisioning requirements, inadequate debt recovery, non - compliance with banking laws, rules and regulations and significant exposure to the capital market through share and margin loans". Okpara (2009) ascertained that one of "the factors that impacted the most on the performance of the banking system in Nigeria were fraudulent practices". "A worrisome development in fraud and fraudulent activities is increased rate of bank staff involvement especially in forgery cases and especially most forgeries are perpetuated by internal staff or by outsiders who act in collusion with employees of the bank" (Chiezey \& Onu, 2013). These painful and disgusting developments have continued to prompt the attention of researchers to constantly re-examine the influence and extent of frauds on banking sector financial performance at least for the purpose of policy perspective. The rest of this article is structured as follows: Section two contains the review of related literature, section three is the methodology, section four concerns with analysis and discussion of findings while section five is conclusion and recommendations.

\section{Literature Review}

\subsection{Theoretical Framework}

In examining the association between frauds and the financial performance of banks in the Nigerian banking industry, this study relies on the fraud triangle theory, differential association fraud theory, fraud scale theory, fraud diamond theory and self -control theory. These theories are so chosen for this study in that they will enable 
the researcher make a robust evaluation of fraud, how it is perpetrated, its effects and implications to the performance of corporate organizations particularly banks in the banking sector. The fraud triangle theory as developed by Donald Cressey in 1971 states that there are three basic factors which precipitate people to commit fraud. These factors encompass perceived pressure, perceived opportunity and perceived rationalization. According to the tenet of this theory, every perpetrator of fraud is influenced by perceived pressure which could be worked related or personal related sources. The perceived pressure serves as a motivating factor for the person to perpetrate the fraud with a view to meeting the expectation, precisely the financial pressure confronting him/her. Psychologically, the individual perpetrating the fraud believes he/she cannot be caught in the very act. However, this theory supports the notion that for such individual to commit fraud, there must existed weak internal control and punishment before such act is carried out with levity. Consequently, this makes the fraudster to easily find a way to rationalize his/her action as an acceptable one.

According to Cressey (1971), with the fraud triangle theory, individuals who perpetrate fraud in corporate organization do so because they see the opportunity or loophole for it and then take advantage of it. The author however holds the view in this theory that fraud can be significantly reduced given that the pressure, opportunities and rationalization of individuals are addressed by corporate organization. While this theory laid the foundation of the primary reason people tend to commit fraud in corporate organization, it fails to extract out certain internal and external factors that could precipitate persons to commit frauds, thereby adversely affecting the value of such firms. This obvious theoretical gap led to the evolvement of other theory like the differential association fraud theory as developed by criminal scholar, Edwin Sutherland in 1974. The theory states clearly that individuals learn to commit fraud through associations with other fraudsters. This goes to affirm the axiom: 'it takes maintenance of a tie with a thief for another individual to learn the mechanics of being a thief and hence become a professional thief'. The gap in this theory is that while it focuses on how individuals easily learn to become criminals and perpetrated fraud, it fails to reveal why they easily become criminals or fraudsters. Although the theory holds that if fraud is to be drastically reduced, then there is need to vary the ethics of the business. Therefore, until management address or changes the business ethics, in the context of this theory, the tendency for fraud to thrive is likely or constant.

In evaluating the fraud triangle theory, Albrecht, Howe and Romney in 1984 came up with the fraud scale theory. They developed this theory based on the lacuna found in the fraud triangle theory which fails to include personal integrity instead of rationalization. In their view, they see personal integrity as the code of ethical behaviour each person adopts. This theory really was a further rework on both the fraud triangle theory and differential association fraud theory. As noted by Onwujiuba (2013), this theory is particularly applicable to financial reporting fraud where analyst forecasts, management's earnings guidance, a history of sales and earnings growth are more observed. The view and expression of Albrecht et al (1984) under the fraud scale theory vary markedly from every other aforementioned theory. In building on the gap observed in the above examined theories of fraud, Wolfe and Hermanson (2004) had to develop the fraud diamond theory. According to this theory, for fraud to really occur, four basic elements must be present and they include incentive, opportunity, rationalization and individual's capability. This theory buttresses the point that an individual's personal abilities and traits play a major role in determining whether or not fraud may actual take place within the organization none the less the presence of the other three factors which include pressure, opportunity and rationalization. Under this theory, weak internal control in the organization creates a loophole for fraud to easily be perpetrated. Covertly, if there is a right person with the right capability to design the opportunity for fraud to be committed, fraud occurrence stands to be drastically minimized or at most may never take place. According to Onwujiuba (2013), this theory has led to the findings that most frauds in organizations are perpetrated with about $59 \%$ by middle level management. The researcher stressed that the middle level management is composed of people who have the experience on the job and smart enough to realize the opportunities in order to take advantage of them.

This theory also states that the characteristics of persons with capabilities to perpetrated fraud in the organization to include the person's ability to exploit the opportunity to commit fraud, the individual must be smart enough to understand and exploit the internal control weaknesses, the perpetrator has the ego and 
self-confidence, he/she has the capability to coerce others to commit concealed fraud, he/she must possess persuasive personality and can effectively tell lies consistently and above he/she is able to handle stress easily. The fraud diamond theory fails to recognize the adverse implication of lack of self-control and discipline at minimizing the occurrence of fraud and fraudulent practices in corporation organizations. This shortfall led to the development of the self - control theory by Gottfredson and Hirschi (1990). They state that individuals with low levels of self - control are more likely to commit a wide variety of- crime such as fraud and crime related behaviours.

According to McMullen (1999), individuals who lack self - control tend to be impulsive, insensitive, physical as opposed to mental risk taking, shortsighted and non-verbal. Similarly, the theory asserts that low self - control is learned from childhood through parental nurture. The researchers further argue that inconsistent parenting practices result in children who are unable to delay gratification, avoid risky behaviour, control their impulses and consider the feelings of others. This robust assessment of the various theories of fraud succinctly reveals the reason and intention behind the occurrence of frauds in corporate organization. So, they underpin every empirical analysis of this study and consequently the nexus fraud has on the financial performance of banking sector. Understanding the working knowledge of these theories suffices to unravel the root causes of fraud and how management can employ skillful approach at handling fraud with a view to enhance performance and engendering the wealth of the shareholders in the corporate organization at large particularly the banking sector.

\subsection{Empirical Review}

Chiezey and Onu (2013) examined how fraud and fraudulent practices affect the performance of banks in Nigeria for the period 2001-2011. They used 24 commercial banks in Nigeria in the reference period. The nexus between fraud cases and other variables were estimated using the Pearson product moment correlation. Multiple regression analysis was used to examine the impact fraud and fraudulent practices have on bank performance in the period. The empirical findings obtained shows that the percentage of mobilized funds lost to fraud was highest between 2001 and 2005. The study also revealed that due to the stringent measures adopted by the regulatory bodies to tackle the menace of fraud and fraudulent activities, there was a significant decrease between 2006 and 2011. The conclusion they drew was that fraud and fraudulent activities inflict severe financial difficulties on banks and their customers.

Chiezey and Onu (2013) stressed that a worrisome development in fraud and fraudulent activities is increased rate of bank staff involvement especially in forgery cases. Okpara (2009) report indicates there is high involvement of bank staff in fraud and fraudulent practices. For example, Nwaze (2009) affirms the fact that most fraud cases are perpetuated by internal staff or by outsiders who act in collusion with employees of the bank. According to an NDIC publication, about 1914 bank staff of various banks was involved in bank frauds between 1994 and 1996. Equally worrisome is the rise in the number of top management staff that have been indicted or accused of engaging in bank fraud. The NDIC annual reports show that a total of 3, 911 staff were involved in bank fraud. Owolabi (2010) empirically examined the implication of fraud on banks' performance in Nigeria using the ordinary least square multivariate regression method. The finding made was that fraud results to bank poor performance and failure.

Ajayi (2014) determined the impact of frauds on the financial performance of banks in Nigeria using multiple regression method. The results showed that a causal relationship exists between the total amounts, number of cases, number of fraudulent staff, fraud and forgery activities and bank performance. Chelangat (2014) examined the effects of frauds on banks' performance in Kenya using Pearson correlation matrix and multiple regression method. The result indicates that there is a positive relationship between dimension of frauds and bank financial performance. Adediran and Olugbenga (2010) examined the impact of fraud on banks' performance in Nigeria using multiple regression method. They found that fraud cases, fraud amount and losses do not statistically impact on bank financial performance. 
Kanu and Okafor (2013) determined the effects of frauds on banks' financial performance in Nigeria using ordinary least square multiple regression method. They ascertained that frauds erode the asset value of banks, and is not statistically significant. Imegi and Ogbeide (2017) undertook an empirically assessment of frauds on banks' liquidity in Nigeria for the period 1994 to 2015 using Johansson co-integration technique and error correction mechanism. The findings revealed that total number of fraud cases, actual amount involved in the fraud and the loss associated with it negatively affect banks liquidity position in the long- run, though the effect is not as strong as in the short run. The paper concluded that fraud is a key variable that depletes the banks' ability to meet up with short term obligation as well as impinge on the ability to effectively maximize the wealth of the shareholders. The study further suggested that the services of the forensic accountants be given utmost priority by banks and all concerned stakeholders so as to constantly and effectively monitor the internal control system, report levels of frauds, as well as come up with a model to fight the effect of frauds on banks' operation. These mixed findings still leave some gaps in literatures for re-examination; hence the need for this empirical research, particularly to ascertain how frauds determine the financial performance of banking sector in Nigeria.

\section{Methodology}

This research used both the exploratory and longitudinal research designs. The population of this study is principally related to the banking industry in Nigeria. Particularly, the sample period 1993-2016 is selected using purposive sampling technique; and this represents 25 annual observations. The data for this study were generated from secondary sources mainly from the annual reports published by the Nigerian Deposits Insurance Corporation (NDIC) various issues.

Model Specification - The model used in this study was underpinned to the works of Adediran and Olugbenga (2010) where they determined the effect of fraud on commercial bank's performance in Nigeria, and used the model:

$$
\mathrm{CBINV}=\beta \mathrm{o}+\beta 1 \mathrm{TCR}+\beta 2 \mathrm{TAI}+\beta 3 \mathrm{AEL}+\mathrm{Ut}
$$

Where in:

CBINV $=$ Commercial Banks Investment

TCR concerns the total number of cases of fraud reported

TAI represents total amount involved

$\mathrm{AEL}=$ Actual/expected loss

$\mathrm{Ut}=$ error term

$\beta o=$ intercept

The above model is modified and adapted. The mathematical form of the model is:

Bank performance $=\mathrm{f}$ (total number of cases of fraud reported, total amount involved in fraud, actual expected loss). However, the stochastic form of the model is stated below:

$$
\Delta R O E_{i t}=\beta_{0}+\beta_{1 \Delta N F C_{i t-i}}+\beta_{2 \Delta T A I_{i t-i}}+\beta_{3 \Delta L O S s_{i t-i}}+\beta_{4 \Delta S I Z E_{i t-i}}+\lambda E C M_{t-1}+\varepsilon_{t \ldots \ldots . .(1)}
$$

Where in:

$\triangle R O E$ represents change in return on equity of the banks

$\beta_{1}$ to $\beta_{4}$ represents coefficient of the parameters of estimation

$i$ represents cross- section, i.e aggregate of the banks in the Nigerian banking sector and $t$ is the period in question.

Д ROE represents change in return on equity.

NFC is number of fraud cases

TAI is total amount involved in the cases of fraud reported

LOSS is total actual/ expected loss involved in the cases of fraud reported

SIZE represents the number of banks

ECM is used to represent the error correction model

A priori expectations are $\beta_{1}$ to $\beta_{4}<0$. 
This implies these independent variables are expected to negatively influence the various bank performance indicators.

Method of data analysis - The research used Johansen co-integration and error correction mechanisms for the purpose of data analysis. They were used to establish both short run and long run dynamic relationships among time series variables. Prior to this econometric procedure, unit root test tests were performed on the variables. The aim is to ensure there is no spurious regression result and also the result is stable for policy prescriptions.

\section{Empirical analysis and discussion of results}

Table 1 represent the unit root test result. The ADF results revealed that at first difference all the variables were stationary at level, an indication that there is unlikely presence of spuriousness in the result.

\section{Table 1}

Summary of the unit root test result

\begin{tabular}{lccl}
\hline \multicolumn{1}{c}{ Variables } & ADF statistics & T-critical values & Remark \\
\hline ROE & -4.234 & -.2 .998 & Stationary at first difference \\
NFC & -3.322 & -3.020 & Stationary at first difference \\
TAI & -5.207 & -3.004 & Stationary at first difference \\
LOSS & -8.018 & -3.004 & Stationery at first difference \\
SIZE & -7.636 & -3.001 & Stationery at first difference \\
\hline
\end{tabular}

Source. Author's computation from E-Views 8.0 version (2018).

\section{Table 2}

Johansen Unrestricted Co-integration Results

\begin{tabular}{ccccc}
\hline Null hypothesis & Trace statistics & Critical value at 5\% & Maximum Eigen value & Critical values at 5\% \\
\hline $\mathrm{R}=0$ & 107.980 & 69.818 & 44.320 & 33.876 \\
$\mathrm{R} \leq 1$ & 63.660 & 47.856 & 36.688 & 27.584 \\
$\mathrm{R} \leq 2$ & 26. & 29.797 & 17.844 & 21.131 \\
$\mathrm{R} \leq 3$ & 9.127 & 15.494 & 4.914 & 14.264 \\
$\mathrm{R} \leq 4$ & 4.212 & 3.841 & 4.212 & 3.841 \\
\hline
\end{tabular}

Source. Computed from E-View 8.0 version (2018).

Table 2 above shows that there are at least 2 co-integrating equations under the trace statistics and maximum Eigen value. The result is an indication that there exists a long run relationship between frauds and the financial performance of banking in Nigeria.

Table 3

Parsimonious Error Correction Mechanism Result - Dependent Variable: DROE (-5)

\begin{tabular}{|c|c|c|c|c|}
\hline Variables & Coefficient & Std-Error & t-ratio & Prob. \\
\hline $\mathrm{C}$ & -0.789 & 6.456 & -0.122 & 0.904 \\
\hline $\operatorname{DNFC}(-3)$ & -0.038 & 0.017 & -2.145 & 0.051 \\
\hline DTAI(-1) & -1.159 & 0.941 & -1.230 & 0.240 \\
\hline DLOSS(-1) & 1.516 & 2.222 & 0.682 & 0.507 \\
\hline DSIZE(-1) & -0.069 & 0.140 & -0.495 & 0.628 \\
\hline $\operatorname{ECM}(-1)$ & -0.415 & 0.187 & 2.216 & 0.045 \\
\hline R-squared & 0.590 & & & \\
\hline Adjusted R-squared & 0.515 & & & \\
\hline F-statistic & 4.244 & & & \\
\hline \multirow[t]{3}{*}{ Prob (F- statistic) } & 0.000 & & & \\
\hline & Durbin- Watson & & & \\
\hline & Statistic $=2.070$ & & & \\
\hline
\end{tabular}


Table 3 concerns the parsimonious error correction result. It can be observed that the adjusted coefficient of determination puts the systematic variation at $52 \%$ approximately, leaving the remaining percentage unexplained as a result of the stochastic error term. Judging by $\mathrm{R}^{2}$ and its adjusted counterpart, the estimated model is weak to an extent. The F-statistics at 2.507 with $p=0.000$, shows that at $1 \%$ significant level, the alternative hypothesis which specifies a systematic relationship between the dependent variable and all the included regressors can be accepted and the overall goodness of fit of the model. To examine the impact of each of the independent variables on the dependent variable, the estimated coefficients are considered. As observed, a three period lag of number of fraud cases (DNFC-3) has negative coefficient (-0.038 units) and is statistically significant at 5\% level $(\mathrm{P}=0.051)$. One period lags of total amount involved in the fraud (DTAI-1), one period lag of size (DSIZE-1) have negative signs on financial performance of banks in the Nigerian banking sector (-1.159 units, and -0.069); they were not statistically significant at $5 \%$ level while one period lag of LOSS (DSIZE-1) have positive coefficients or sign on the financial performance of banks and it is not statistically significant at $5 \%$ level. The ECM coefficient is negative $(-0.415)$ and is statistically significant at 5\% $(p=0.045)$. The error correction mechanism coefficient result can thus serve as error equilibrium. It is a pointer that any temporary deviation from the long-run equilibrium between banking sector performance and the regressors can be restored at the rate of $41.57 \%$. Finally, the Durbin-Watson statistic put at 2.070 which can be approximated to 2 shows the absence of first-order serial dependence, thus making the result useful for policy perspective.

One of the factors that have continued to erode both the corporate image and earnings of banks in the Nigerian banking sector is fraud and fraud related practices. In fact, some banks have closed down occasioned partly by the influence of fraud and much more, weak corporate governance practices in the past. In this subsection, the test of the hypotheses and the findings arising from the empirical estimations are robustly discussed and where necessary, the findings are related to prior studies to evaluate consistency or non -consistency. It is true that in the Nigerian financial institutions, banks are susceptible to adverse effect of fraud. The yearly figures on fraud as reported by the Nigerian Deposit Insurance Corporation (NDIC) is alarming and have continued to be on the ascendency. Against the backdrop of this unwholesome occurrence, many researchers have undertaken varying researches to ascertain how frauds affect the financial performance of banks. The results most of them obtained are quite inconclusive. This lacuna as stated earlier is one of the reasons that necessitated this study. Similarly, to the best of the knowledge of the researcher, there exist scanty or no studies that have considered the extent to which frauds have impacted on the financial performance of banking sector in Nigeria. Hence, this study was made to contribute to the debate both on theoretical and empirical fronts. The measure of financial performance in this study is a departure from conventional measurement by prior studies. Rather than employing single accounting measure, the study used pragmatic composite financial performance measures, which indeed both reflect soundness, health, liquidity and ability to resist sudden external shocks. The empirical estimation indicates that the extent with which fraud impacts on the financial performance of banks in the Nigerian banking sector is about approximately on the average. This portends that on the average, fraud eats up the financial performance of banks. This is clearly a reduction in the wealth maximization of the shareholder in Nigerian banking sector. In affirmation to this, the results reveals also that the total number of fraud cases combined, ranging from fraud, forge and forgery, management fraud and others significantly reduce the financial performance under the period this study covers particularly in the short.

However, in the long-run, the extent with which frauds impacts adversely on the financial performance of banking sector in Nigeria is about $63 \%$ and it was statistically significant at $5 \%$ level. The finding obtained here is inconsistent with Chelangat (2014); Adediran and Olugbenga (2010). The contrary finding could be due to differences in sample size (period), financial performance measures and the nature of data used. The empirical finding here is quite consistent with that of Ikpefan (2006); Chiezy and Onu (2013), and it is also to a large extent in tandem with Nwawkwo (2013). Albeit, the uniqueness of the finding of this study is that it has revealed the extent to which frauds impacts on the financial performance of banks in the Nigerian banking sector both in long-run and short-run. It must be stated here that one of the inadequacies of this study finding in this regard is that it failed to consider the implication and extent of the impact of the individual different types or component 
of frauds that are perpetrated in banks on the financial performance; thus creating a gap in literature for future researcher to examine, perhaps with similar or dissimilar statistical and econometrical tools.

\section{Conclusion and Recommendations}

This research empirically assessed the extent frauds influence the financial performance of banking sector in Nigeria. The robust results obtained portray that the greatest effect of frauds is on the area of banks capital base where it was intuitively observed that in the long run frauds could erode the capital of banks significantly in the short run, followed by asset quality and earnings, donated as return on equity. The overall implication of this is that the financial soundness, liquidity and ability of banks to resist sudden external shocks may be difficult. Premised on the empirical findings made, it is recommended that since majority of banking services are carried out electronically, banks should always deploy updated cutting-edge technology (both hard and soft ware) that will constantly increase the chances of detection, prevention and possibly eliminate the incidence of bank fraud associated with the internet with a view to enhancing the financial performance. This research therefore has significantly contributed to existing literature in the area of the association between frauds and bank performance. It is the first empirical research to the best of the researcher's knowledge to actually focus on the implication of frauds on individual bank financial performance in the banking sector of Nigeria.

\section{References}

Adediran, D., \& Olugbenga, A. K. (2010).Impact of frauds on banks' performance in Nigeria. The Nigerian Academic Forum, 19(1), 1-5.

Adeyemo, K. A. (2012). Frauds in Nigerian banks: nature, deep-seated causes, aftermaths and probable remedies. Mediterranean Journal of Social Sciences, 3(2), 279-289

Ajayi, M. A. (2014). Determinants of fraud in Nigerian Banking industry. Journal of Finance and Research, 2(1), 6-18.

Albrecht, W. S., Howe, K. R., \& Romney, M. B. (1984). Deterring fraud: The internal auditor's perspective. Institute of Internal Auditors Research Foundation.

Chelangat, B. (2014). The effect of fraud on the financial performance of deposit taking savings and credit co-operative societies in Kenya. Journal of Finance, 12(4), 112-140.

Chiezy, U., \& Onu, A. J. C. (2013). Impact of fraud and fraudulent practices on the performance of banks in Nigeria. British Journal of Arts and Social Sciences, 15(1), 12-28.

Cressey, D. (1971). The new fraud triangle model. Journal of Emerging Trends in Economics and Management Sciences, 3(3), 191-195.

Edwin, S. (1974). Exploring a new element of fraud: A study on selected financial accounting fraud cases in the World. American International Journal of Contemporary Research, 2(6), 112-121.

Gottfredson, G., \& Hirschi, P. (1990). The psychology of fraud. Trends and issues in crime and criminal justice. Australian Institute of Criminology, Canberra.

Idolor, E. J. (2010). Bank frauds in Nigeria: underlying causes, effects and possible remedies. African Journal of Accounting, Economics, Finance and Banking Research, 6(6), 2-80.

Ikpefan, A. O. (2013). Growth of bank frauds and the impact on the Nigerian banking industry [Doctoral dissertation]. Department of Banking and Finance, Covenant University, Ota, Nigeria.

Imegi, J. C., \& Ogbeide, S. O. (2017). Empirical assessment of frauds on banks' liquidity: Evidence from Nigeria. International Journal of Arts and Humanities, 6(2), 161-170. https://doi.org/10.4314/ijah.v6i2.12

Kanu, S. I., \& Okafor, E. O. (2013).The nature, extent and economic impact of fraud on bank deposits in Nigeria. Interdisciplinary Journal of Contemporary Research in Business, 4(9), 253-265.

McMullen, H. (1999). The new fraud triangle. Journal of Emerging Trends in Economics and Management Sciences, 3(3), 13-34.

Nigeria Deposit Insurance Corporation (NDIC) annual reports and accounts (2000-2014). Lagos, Nigeria. 
Ogbeide, S. O.

Nwankwo, O. (2013). Implications of fraud on commercial banks performance in Nigeria. International Journal of Business and Management, 8(15), 144-150. https://doi.org/10.5539/ijbm.v8n15p144

Nwaze, J. K. (2009). An empirical analysis of social impact of fraud on the Nigerian banking industry. Research Journal of Finance and Accounting, 7(4), 12-17.

Ogechukwu, O. S. (2014). Liquidity management and commercial banks' profitability in Nigeria. Research Journal of Finance and Accounting, 2(7/8), 24-38.

Okpara, A. O. (2009).Analysis of frauds in banks: Nigeria's experience. European Journal of Business and Management, 6(31), 90-99.

Olatunji, R., \& Adekola, W. (2014). The determinants of financial performance of quoted banks in Nigeria: A study of selected deposit money banks. International Journal of Education and Research, 1(10) 1-18.

Onwujiuba, J. O. (2013). Bank fraud and its effect on bank performance in Nigeria. Department of Banking and Finance, Faculty of Management Sciences, University, Enugu State, Nigeria.

Oseni, F. O. (2006).The effects of financial fraud and liquidity on financial performance of commercial banks in Kenya. College of Humanities and Social Sciences. Retrieved from http://erepository.uonbi.ac.ke:8080/xmlui/handle/123456789/58568

Owolabi, S. A. (2010). Fraud and fraudulent practices in Nigeria banking industry. African Research Review, 4(3b), 240-256. https://doi.org/10.4314/afrrev.v4i3.60263

Wolfe, D., \& Hermanson, D. R. (2004). The fraud diamond: Considering four elements of fraud. The CPA Journal, 74(12), 38-42. 